\title{
The natural history of Möbius syndrome in a 32-year-old man
}

\section{Historia naturalna zespołu Möbiusa u 32-letniego mężczyzny}

\author{
Monika Chorąży', Ryszard Leśniewicz', ${ }^{2,3}$ Renata Posmykk, Dorota Halicka', Aneta Zalewska ${ }^{4}$, Anna Wincewizz-Pietrzykowska ${ }^{4}$ \\ Kamil Chorąży ${ }^{5}$, Wiesław Drozdowski
}

'Department of Neurology, Medical University of Bialystok, Poland

2 Department of Reproduction and Gynaecological Endocrinology, Medical University of Bialystok, Poland

${ }_{3}^{3}$ Podlaskie Centre of Clinical Genetics in Bialystok, Poland

${ }^{4}$ Maxillofacial and Plastic Surgery Department, Medical University of Bialystok, Poland

5Karedent, Dental Clinic in Bialystok, Poland

Neurologia i Neurochirurgia Polska 2011; 45, 1: 74-79

\begin{abstract}
Möbius syndrome (OMIM\# 157900) is an extremely rare congenital entity involving bilateral or unilateral palsy of the facial nerve, usually with dysfunction of other cranial nerves (second, third, fifth, sixth, ninth, tenth and twelfth). It was estimated that Möbius syndrome occurs in 1 of 50000 live births. The aetiology and the pathogenesis of the syndrome remain unknown. The majority of published cases were sporadic. We report on the natural history of a 32-year-old man with de novo Möbius syndrome. The diagnosis was established at the age of 9 months due to partial bilateral facial and abducent nerve palsy. Additionally, the patient demonstrated failure to thrive during infancy and childhood, many dysmorphic features, lower limb anomalies, and hypogonadism in adulthood, but his intelligence was in the normal range. The low quality of life of the patient with Möbius syndrome is emphasized.
\end{abstract}

Key words: Möbius syndrome, facial nerve palsy, cogenital disorder, bilateral/unilateral involvement.

\section{Streszczenie}

Zespół Möbiusa (OMIM\#157900) należy do niezwykle rzadkich schorzeń wrodzonych; dochodzi w nim do obustronnego bądź jednostronnego porażenia nerwu twarzowego, zwykle z dysfunkcją innych nerwów czaszkowych (II, III, V, VI, IX, X oraz XII). Szacuje się, że zespół Möbiusa występuje z częstością 1 na 50000 żywych urodzeń. Etiologia i patogeneza zespołu pozostaje nadal nieznana. Zdecydowana większość opublikowanych przypadków występowała sporadycznie.

W pracy przedstawiono historię naturalną zespołu Möbiusa powstałego de novo u mężczyzny liczącego obecnie 32 lata. Diagnoza została postawiona w wieku 9 miesięcy na podstawie stwierdzenia objawów częściowego porażenia nerwu twarzowego oraz odwodzącego. Dodatkowo u pacjenta stwierdzano zaburzenia wzrastania w okresie niemowlęcym i dziecięcym, cechy dymorficzne twarzoczaszki, anomalie kończyn dolnych, hipogonadyzm po okresie dojrzewania oraz inteligencję w granicach normy. Zaakcentowano niską jakość życia chorego na zespół Möbiusa.

Słowa kluczowe: zespół Möbiusa, porażenie nerwu twarzowego, schorzenie wrodzone, porażenie obustronne/jednostronne.

Correspondence address: Monika Chorąży, MD, PhD, Department of Neurology, Medical University of Bialystok, Poland, Skłodowskiei-Curie 24 A, 15-276 Białystok, fax: +48 8574686 08, e-mail: chorazym@op.pl

Received: 21.06.2010; accepted: 15.09.2010 


\section{Introduction}

Möbius syndrome (MBS; OMIM\#157900) is an extremely rare congenital disorder. Approximately 300 cases have been described so far. The prevalence of MBS was estimated as 1 per 50000 live births [1]. Clinically, it is characterized by the inability to move the eyes laterally and by the lack of facial expression. The first description of congenital facial diplegia was presented by von Graefe in 1880. The new condition was defined further as a syndrome in 1888 by the neurologist P.J. Möbius, from whom it derives its name [2]. The hallmark symptoms of MBS appear mainly due to bilateral or unilateral palsy of two cranial nerves: the facial nerve and the abducens nerve. MBS can be followed by symptoms caused by palsy of other cranial nerves (second, third, fifth, sixth, ninth, tenth and twelfth) $[3,4]$. Besides typical neurological symptoms, additional dysmorphic features can be observed. The most frequent traits are: facial asymmetry, hypertelorism, epicanthus, microphthalmia, micrognathia, bifid uvula, high-arched cleft palate, teeth defects, and external ear anomalies. Malformations involving other organs and systems may also appear (small penis, hypoplastic testes, upper and lower limb deformities, such as brachydactyly and syndactyly, and various muscular defects). Mild intellectual disability can also be observed $[4,5]$.

The majority of the published cases were sporadic. Approximately $2 \%$ of cases had a genetic basis [1]. In familial cases, different types of inheritance have been observed: autosomal dominant (AD) [6-9], autosomal recessive (AR) [6] or X-linked recessive (XR) [10]. The reduced penetrance and variable expression among the family members may wrongly identify the affected person as a sporadic case, as was proven by Verzijl et al. in a large Dutch family with AD mode of inheritance. The exact mutation of any single gene associated with MBS is still unknown and genetic heterogeneity was suggested by several cytogenetic studies. Kemer $e$ et al. proposed localization of a gene in familial AD congenital facial paralysis to chromosome 3q21-22 [11]. Verzijl et al. found linkage to a 3.7-cM locus at chromosome 10q21.3-q22.1 for AD MBS [8]. Cytogenetic findings of reciprocal chromosomal translocation (RCT) between chromosomes 1p34 and 13q13 in 7 patients with MBS reported by Ziter $e t a l$. [12] suggested the critical region location for this syndrome. Another report of deletion on chromosome 13q12.2 allowed the gene locus region to be widened to 13q12.2-q13 [13]. Two other RCT, $\mathrm{t}(1 ; 11)(\mathrm{p} 22 ; \mathrm{p} 13)[14]$ and $\mathrm{t}(1 ; 2)(\mathrm{p} 22 ; \mathrm{q} 21.1)$ [15], were found in sporadic cases and suggested that another gene for MBS is located on chromosome 1p22.

The aetiology and the pathogenesis of the syndrome are still discussed. Two hypotheses have been postulated. The first is developmental rhombomeric defect including the facial cranial nerve due to a genetic cause $[6,16,17]$. The second hypothesis, a vascular one, suggests hypoperfusion or occlusion in the watershed zones of the lower brainstem [1].

Exposure to infections, alcohol, drugs (cocaine), or medicines (thalidomide, ergotamine, zonisamide or misoprostol) has also been considered as a teratogenic factor of MBS in several articles [18-24].

The main aim of our work was to present the natural history of a male patient with MBS observed from 9 months up to 32 years of age and to point out his impaired quality of life due to the diagnosis of a congenital neurological disorder. Such investigations are a long-term process and require good collaboration between the patient, his or her family and many medical specialists. Thus far, we have not found any longterm follow-up of any MBS patient.

\section{Case report}

\section{Anamnesis}

The proband was born as the first and only child to young (mother 23, father 25 years old) non-consanguineous parents. The family history was unremarkable for any neurological or genetic disorders. The first trimester of the pregnancy was complicated by bleeding and imminent abortion. Uncomplicated vaginal delivery was at term.

\section{Clinical data}

After birth the newborn was classified as hypotrophic with intrauterine growth retardation. Birth weight was $2300 \mathrm{~g}$, length $52 \mathrm{~cm}$, head circumference $31 \mathrm{~cm}$, thorax circumference $30 \mathrm{~cm}$, and Apgar score was 10 . The newborn period was complicated by sucking and swallowing difficulties. A high-arched, narrow palate, pharyngeal insufficiency and a large, asymmetric tongue were suspected as the major causes of those problems. Surgical correction of the tongue was performed. Excessive drooling of saliva was noted. The diagnosis of MBS was established by a neurologist at the age of 9 months 


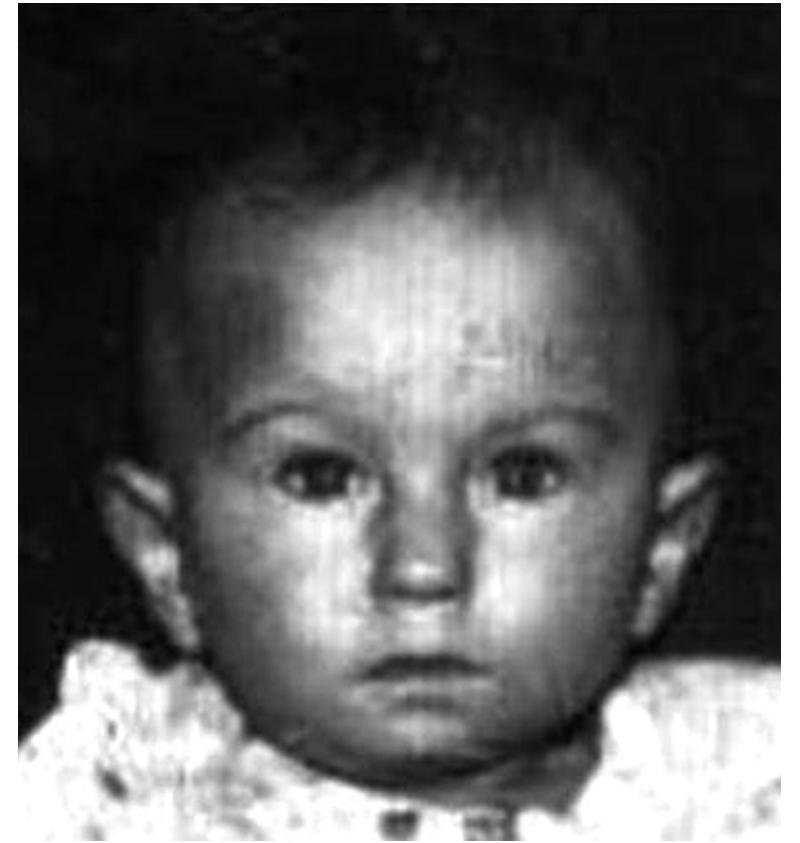

Fig. 1. Facial appearance of the patient with Möbius syndrome at 9 months



Fig. 3. Facial appearance of the patient with Möbius syndrome at 14 years

(Fig. 1) due to poor facial expression, especially during crying, incomplete closure of the eyelids during sleep, nystagmus and inability to move his eyes laterally. Developmental milestones were delayed due to mild muscular hypotonia. The neonate received a course of inten-



Fig. 2. Facial appearance of the patient with Möbius syndrome at 7 years

sive rehabilitation. He began to sit at 10 months, to crawl at 15 months, to stand with support at 18 , and to walk at 20 months. The boy was able to say a few simple words at 24 months, and to construct sentences at 3 years, but his speech was unclear, with impaired articulation. Additionally, club feet were noted. At the age of 5 years, the patient underwent ophthalmological surgery for nystagmus. During childhood (Figs. 2 and 3) he was rather small and thin. Poor weight gain due to gluten intolerance was diagnosed and appropriate dietetic treatment was applied. He finished primary school and high school. Delayed puberty was noticed, but the patient avoided any hormonal testing or endocrinological consultation. In a neuropsychological test his intelligence was assessed as in the lower range of normal. The young man was very ambitious, entered university (law faculty) and successfully passed all exams.

At the last physical examination at 32 years his height was $158 \mathrm{~cm}\left(<3^{\text {rd }}\right.$ centile), weight $49 \mathrm{~kg}\left(<3^{\text {rd }}\right.$ centile), head circumference $52 \mathrm{~cm}\left(<3^{\text {rd }}\right.$ centile). Neurological examination revealed bilateral incomplete facial and abducens nerve paralysis. Additionally, many observed symptoms were due to paralysis of oculomotor, vagus and hypoglossal nerves. The major problems were: lack of facial expression, known as 'mask-likeface', with inability to smile; absence of lateral eye movement; absence of blinking; eye sensitivity due to inability to squint; short, narrow, asymmetric tongue with 
limited movements; asymmetry of the soft palate, where the left side was higher than the right one; and the palate and pharyngeal reflexes were weak. Speech was impaired, with articulation problems. Reflexes in upper and lower limbs were symmetrical and equal, with no clonus.

Intellectual functioning was assessed according to the WAIS-R neuropsychological test and gave a result in the lower range of normal. The patient had major difficulties with and was slow at analyzing information, especially concerning selection of visual material. Slow learning and further processing of visual material was prominent. Difficulties in audio-verbal tasks were evident. There was low ability to solve a task where visual-motor interaction was necessary. The patient had significant difficulty with tasks where observation of moving objects was required.

Laryngological testing revealed low-set ears with low external auditory canals. Hearing impairment was diagnosed by audiometry testing $30 \mathrm{~dB}$ for low tones and $70 \mathrm{~dB}$ for high 6-8 $\mathrm{kHz}$ tones. Tympanometry was bilaterally type A. Central Weber and bilateral Rinne test were positive. The larynx and pharynx were difficult to examine because of anatomical constraints.

In ophthalmic examination absence of lateral horizontal eye movement, incomplete upper movement of the left eye, features of secondary retraction syndrome without nystagmus, congenital fibrosis of the extraocular muscles, and left eye suppression during bilateral vision were observed. The pupillary responses were normal. Normal retinal vessels and discs were present on fundoscopy.
An intra-oral examination revealed malocclusion (median mandibular line is moved toward the right side), oligodontia, and hypofunction of the perioral muscles, cheeks and tongue.

Asymmetric paranasal sinuses $(\mathrm{L}<\mathrm{R})$ were seen on X-ray. Pantomograph examination revealed lack of the eighth teeth. In magnetic resonance imaging (MRI), no abnormalities were found.

Laboratory investigations revealed normal values for routine chemistry except for low serum testosterone, LH and FSH levels. Chromosomal analysis showed a normal male karyotype $(46, \mathrm{XY})$.

\section{Morphological phenotype}

Evaluations of the morphological phenotype were performed by a clinical geneticist at 9 months and at 7 , 14 and 32 years (Fig. 4). In infancy the boy's face was round, the forehead high and prominent, eyes with upward slanting palpebral fissures, broad nasal root, short nasal bridge, small mouth fissure, micrognathia, and prominent, low-set ears. With age, his face became longer, the nasal bridge longer, and slight facial asymmetry was noticed at 14 years. The last examination at 32 years revealed: low stature, thin build, scanty adipose tissue, microcephaly, triangular face, flat zygomatic regions, synophrys, dense, laterally descending eyebrows, deep-set eyes, narrow, asymmetric palpebral fissures, upward slanting left palpebra, hypertelorism, narrow mouth fissure, narrow mucous upper and lower lips, narrow, high-arched palate, long uvula, malocclusion, broad nasal root, long, broad, asymmetric nasal bridge,
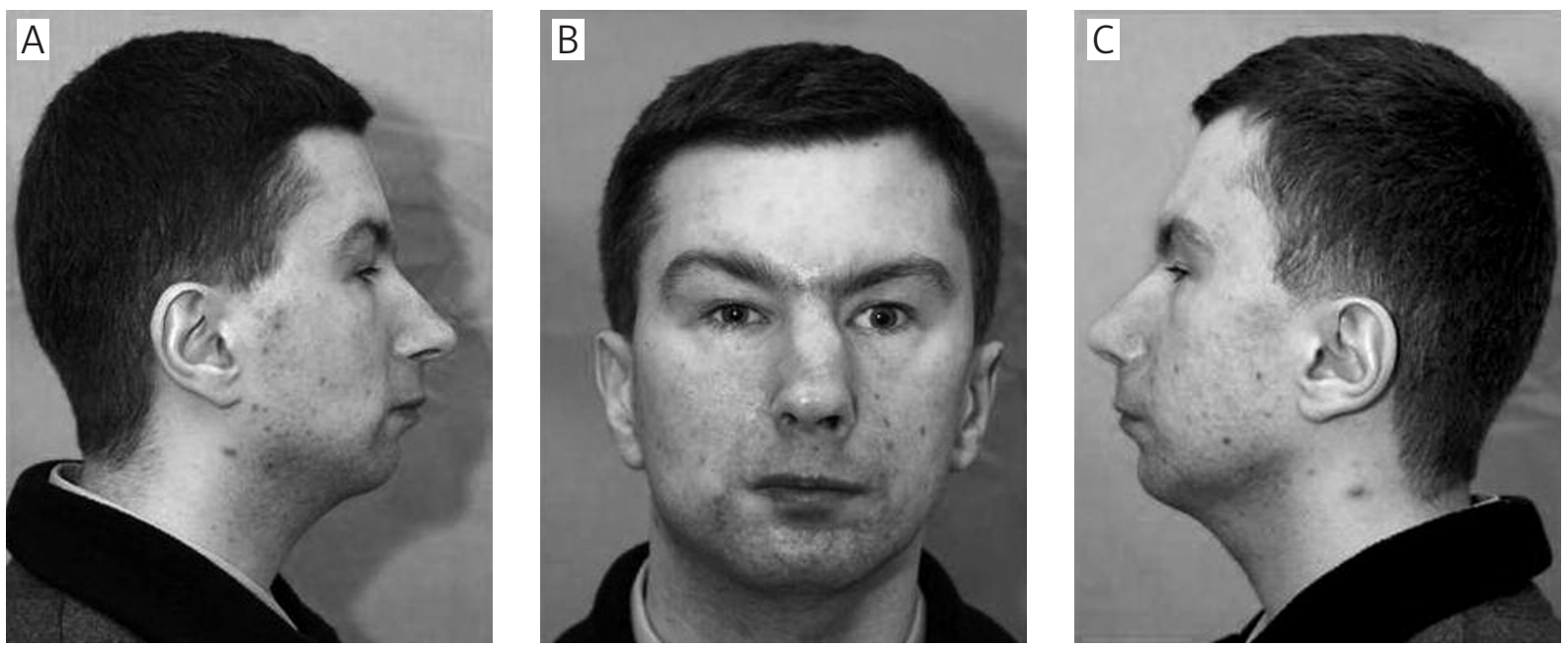

Fig. 4. Right profile, face on and left profile view of the patient with Möbius syndrome at 32 years 
long nasolabial distance, low-set, posteriorly rotated ears, thin upper and lower limbs, small hands and feet, and hypogonadism. No other skeletal malformations or deficiencies in brachial muscle groups were observed.

\section{Discussion}

The presented male patient was primarily diagnosed by a neurologist due to his partial bilateral facial and abducent nerve palsy, which are typical features required for MBS diagnosis. Additionally, many observed symptoms were due to paralysis of oculomotor, vagus and hypoglossal nerves. The hypoglossal nerve was found to be the third most frequently associated with MBS [4].

Reported radiological outcomes are very variable, from normal findings to different degrees of hypoplasia of the brainstem, especially of the pons and cerebellum, absence of the facial nerve and additional calcifications $[16,17,25]$. In our patient, brain MRI did not reveal any abnormalities.

Dysmorphic features seen in our patient resembled those described in other MBS patients [1,4,26]. Club feet and mild muscular hypotonia were present in infancy, which was also described in other MBS cases [4]. We did not find any evident muscular defects. Audiological testing findings were compatible with the results reported by Griz et al. and Bezzera et al. [27,28]. Low serum testosterone and increased $\mathrm{LH}$ and $\mathrm{FSH}$ were found and confirmed hypogonadotropic hypogonadism in our patient, which is rather uncommon in MBS. We found that the present patient is only the eighth such case reported to date [29-32]. Mental retardation was estimated to occur in 10-15\% of MBS cases [3]. Intellectual functioning of our patient was assessed according to the WAIS-R neuropsychological test and gave a result of normal intelligence in the lower range of the scale. The low score was mainly due to impaired visual-motor skills. The young man was very ambitious and decided to finish his studies. He entered university (law faculty) and successfully passed all exams. The main problem appeared while searching for employment. Facial expressionless and articulation problems were considered a major problem in his social interaction. The man was often mistakenly assumed to be mentally retarded due to insufficient eye movements, facial dysmorphism (facial asymmetry, asymmetric nose, asymmetrically placed palpebral fissures) and dysarthria. Briegel et al. suggested that autistic spectrum disorders might be increased in patients with Möbius sequence, but we did not observe such behaviour in our case [3]. Despite his high education references and very friendly personality, our patient was not able to find any employment and we observed his impaired quality of life due to the diagnosis of congenital non-progressive neurological disorder.

Reports of successful microsurgical reconstruction for restoration of facial movement are very promising. A significant improvement in drooling, drinking, speech, and facial animation with a high degree of patient satisfaction was observed $[33,34]$. The possibility for such therapy should be considered as the main solution for improvement of MBS patients' quality of life.

\section{Acknowledgements}

We are very grateful to our patient for his cooperation and permission for publication of photographs.

\section{Disclosure}

Authors report no conflict of interest.

\section{References}

1. Verzijl H.T., van der Zwaag B., Cruysberg J.R., et al. Möbius syndrome redefined: a syndrome of rhombencephalic maldevelopment. Neurology 2003; 61: 327-333.

2. Moebius P.J. Ueber angeborene doppelseitige Abducens-FacialisLaehmung. Muench Med Wschr 1888; 35: 91-94, 108-111.

3. Briegel W. Neuropsychiatric findings of Möbius sequence a review. Clin Genet 2006; 70: 91-97.

4. Kumar D. Moebius syndrome. J Med Genet 1990; 27: 122-126.

5. Lima L.M., Diniz M.B., dos Santos-Pinto L. Moebius syndrome: clinical manifestations in a pediatric patient. Pediatr Dent 2009; 31: 289-293.

6. Legum C., Godel V., Nemet P. Heterogeneity and pleiotropism in the Moebius syndrome. Clin Genet 1981; 20: 254-259.

7. MacDermot K.D., Winter R.M., Taylor D., et al. Oculofacialbulbar palsy in mother and son: review of 26 reports of familial transmission within the 'Moebius spectrum of defects'. J Med Genet 1991; 28: 18-26.

8. Verzijl H.T., van den Helm B., Veldman B., et al. A second gene for autosomal dominant Möbius syndrome is localized to chromosome 10q, in a Dutch family. Am J Hum Genet 1999; 65: 752-756.

9. Wishnick M.M., Nelson L., Reich E.W., et al. Moebius syndrome with dominant inheritance. Am J Hum Genet 1981; 33: 96A.

10. Journel H., Roussey M., Le Marec B. MCA/MR syndrome with oligodactyly and Möbius anomaly in first cousins: new syndrome or familial facial-limb disruption sequence? Am J Med Genet 1989; 34: 506-510. 
11. Kremer H., Kuyt L.P., van den Helm B., et al. Localization of a gene for Moebius syndrome to chromosome 3q by linkage analysis in a Dutch family. Hum Mol Genet 1996; 5: 1367-1371.

12. Ziter F.A., Wiser W.C., Robinson A. Three-generation pedigree of a Moebius syndrome variant with chromosome translocation. Arch Neurol 1977; 34: 437-442.

13. Slee J.J., Smart R.D., Viljoen D.L. Deletion of chromosome 13 in Moebius syndrome. J Med Genet 1991; 28: 413-414.

14. Donahue S.P., Wenger S.L., Steele M.W., et al. Broad-spectrum Moebius syndrome associated with a 1;11 chromosome translocation. Ophthalmic Paediatr Genet 1993; 14: 17-21.

15. Nishikawa M., Ichiyama T., Hayashi T., et al. Moebius-like syndrome associated with a 1;2 chromosome translocation. Clin Genet 1997; 51: 122-123.

16. Verzijl H.T., Valk J., de Vries R., et al. Radiologic evidence for absence of the facial nerve in Möbius syndrome. Neurology 2005; 64: 849-855.

17. Huang H.T., Hwang C.W., Lai P.H., et al. Möbius syndrome as a syndrome of rhombencephalic maldevelopment: a case report. Pediatr Neonatol 2009; 50: 36-38.

18. Bos-Thompson M.A., Hillaire-Buys D., Roux C., et al. Möbius syndrome in a neonate after mifepristone and misoprostol elective abortion failure. Ann Pharmacother 2008; 42: 888-892.

19. Gonzalez C.H., Marques-Dias M.J., Kim C.A., et al. Congenital abnormalities in Brazilian children associated with misoprostol misuse in first trimester of pregnancy. Lancet 1998; 351: 1624-1627.

20. Jurko A. Jr, Minarik M., Misovicova N., et al. Moebius syndrome associated with hypoplastic left heart syndrome. Bratisl Lek Listy 2009; 110: 361-362.

21. Miller M.T., Ventura L., Strömland K. Thalidomide and misoprostol: ophthalmologic manifestations and associations both expected and unexpected. Birth Defects Res A Clin Mol Teratol 2009; 85: 667-676

22. Shepard T.H. Moebius syndrome after misoprostol: a possible teratogenic mechanism. Lancet 1996; 346: 780.

23. Kanemoto N., Kanemoto K., Kamoda T., et al. A case of Moebius syndrome presenting with congenital bilateral vocal cord paralysis. Eur J Pediatr 2007; 166: 831-833.

24. Smets K., Zecic A., Willems J. Ergotamine as a possible cause of Möbius sequence: additional clinical observation. J Child Neurol 2004; 19: 398.

25. Cattaneo L., Chierici E., Bianchi B., et al. The localization of facial motor impairment in sporadic Möbius syndrome. Neurology 2006; 66: 1907-1912.

26. Scarpelli A.C., Vertchenko T.B., Resende V.L., et al. Mobius syndrome: a case with oral involvement. Cleft Palate Craniofac J 2008; 45: 319-324.

27. Bezerra M.C., Griz S.M., Azevedo G.S., et al. Immittance measures in individuals with Moebius Sequence. Braz J Otorhinolaryngol 2006; 72: 731-736.

28. Griz S., Cabral M., Azevedo G., et al. Audiologic results in patients with Moebiüs sequence. Int J Pediatr Otorhinolaryngol 2007; 71: 1457-1463.

29. Abid F., Hall R., Hudgson P., et al. Moebius syndrome, peripheral neuropathy and hypogonadotropic hypogonadism. J Neurol Sci 1978; 35: 309-315.
30. Baraitser M., Rudge P. Moebius syndrome, an axonal neuropathy and hypogonadism. Dysmorph 1996; 5: 351-355.

31. Brackett L.E., Demers L.M., Mamourian A.C., et al. Moebius sequence in association with hypogonadotropic hypogonadism. J Endocr Invest 1991; 14: 599-607.

32. Jennings J.E., Costigan C., Reardon W. Moebius sequence and hypogonadotrophic hypogonadism. Am J Med Genet 2003; 123: 107-110.

33. Bianchi B., Copelli C., Ferrari S., et al. Facial animation with free-muscle transfer innervated by the masseter motor nerve in unilateral facial paralysis. Oral Maxillofac Surg 2010; 68: 15241529.

34. Terzis J.K,, Konofaos P. Nerve transfers in facial palsy. Facial Plast Surg 2008; 24: 177-193. 